\title{
PLANKTON STUDIES IN A MANGROVE ENVIRONMENT. VII. SIZE FRACTIONATION OF THE PHYTOPLANKTON: SOME STUDIES ON METHODS
}

\author{
(Received 18/10/1968)
}

\author{
J. Tundisi \& C. Teixeira
}

Instituto Oceanográfico da Universidade de São Paulo

\begin{abstract}
SYNOPSIS
A series of experiments on the different methods of measuring the relative uptake of $\mathrm{C}^{14}$, by the various size fractions of the phytoplankton, were carried out in a mangrove swamp of the estuarine type at $25^{\circ}$ south latitude. As a complement, some factors which might influence the relative uptake of the different fractions in inshore waters, were studied. These factors are related, mainly, with the increase on the amount of labelled particulate matter during incubation period, the effect of different pressures in the filtration of the size fractions of the phytoplankton, the use of a range of volumes for the incubation of samples, and the effect of formalin on the fixation of samples, after the incubation period. Based on these results, some suggestions are made for the use of the $\mathrm{C}^{14}$ method in inshore waters.
\end{abstract}

\section{INTRODUCTION}

The separation of the phytoplankton in constituents of various size range, has been object of intensive studies, mainly, in the last few years. The investigations carried out by ATKINs (1945), WooD \& Davis (1956), Steemann-Nielsen \& Jensen (1957), Holmes (1959), Yentsch \& Ryther (1959), Teixeira (1963), Holmes \& Anderson (1963), ANderSON (1964), Mullin (1965), Anderson (1965), Teixeira, Tundisi \& SAntoro (1967) demonstrated that a great part of the phytoplankton will pass through the pores of a fine net.

The significant role of the nannophytoplankton in the primary production, in the oceans and lakes, has been emphasized by SAIJO (1964), SAIJO \& TAKESUE (1965) and Gessner (1959).

By the other hand, these studies have considerable interest, in the possible role played by the different fractions, in the feeding of herbivores. In fact, the knowledge of the various size fractions which are offered to the herbivores is of prime importance in the studies of some feeding relationships as selective grazing.

Ballantine (1953) made a intensive study of the procedures for the estimation of nannophytoplankton, by comparing six different methods; it was de-

Publ. n.* 258 do Inst. Ocean. da USP. monstrated that centrifugation of a living samples followed by determination of the number of organisms, in the concentrate, was the most satisfactory method.

Research on the comparison of the different methods for the assessment of the relative importance of the fractions of the phytoplankton is scarce. In the investigations carried out in Vineyard Sound, Yentsch \& Ryther (1959) estimated the relative importance of net-nannophytoplankton, by chlorophyll content, photosynthesis and cell numbers. The net portion constituted a small percentage of the population, and exhibited marked seasonal trends.

These results agree well, with a seasonal study at $25^{\circ}$ south latitude, (Teixeira et al., 1967) during 1965; the bulk of the population was composed by nannophytoplankton smaller than $50 \mu$, and the net-phytoplankton showed very defined seasonal variation, as demonstrated by the relative uptake of $\mathrm{C}^{14}$.

In the present investigation, attention has been paid to the methods of measuring relative uptake of $\mathrm{C}^{14}$ by the different fractions of the phytoplankton given by Steemann-Nielsen \& Jensen (1957) and Yentsch \& RYther (1959). As a complement, some factors which might influence the relative uptake of $\mathrm{C}^{14}$, by the different fractions, in inshore waters, were studied.

This research was carried out at three stations in a mangrove region of the estuarine type, at $25^{\circ}$ south latitude, during October and November, 1966. 
MATERIAL AND METHODS

\section{1 - Area studied}

Previous investigations, (Teixeira \& Kutner, 1963; Teixeira, Tundisi \& Kutner, 1965) demonstrated that the region studied, has different environmental characteristics, at different geographical positions. Thus, three stations were selected: one, in the inner parts of the lagoon (Maria Rodrigues river), one in the middle region, and one in the entrance of the estuary, subjected to a more marked influence of the coastal water. Sketches of the lagunar region, have been published elsewhere in earlier papers (TEIxeIra et al., 1968; Tundisi \& Tundisi, 1968).

Besides the comparison of methods in these stations, an attempt was made to obtain a complementary information, on the relative importance of the distinct fractions in the area studied.

\section{2 - Methods}

Surface water, was collected at each station in volumes of 8.10 litres, in plastic bottles, and then, brought back immediately to the laboratory to be submitted to the different procedures.

I - a) The sea water was placed into clean, $125 \mathrm{ml}$ pyrex bottles, and inoculated with radioactive sodium bicarbonate. After this procedure, the samples were incubated, during four hours at $25 \pm 1^{\circ} \mathrm{C}$ with approximately 10,000 Lux light intensity, and later filtered through a silk net with $25 \mu$ pore size, and a silk net with $50 \mu$ pore size (STEEMANN-NIELSEN \& JeNSEN, 1957).

After filtration, through the nets, the samples were filtered through $\mathrm{H}$. A. Millipore filters, $25 \mathrm{~mm}$ diameter, $0.45 \mu$ pore size.

A similar treatment was given to another samples, of the same sea water, only that the filtration through the nets, was done before inoculation of radioactive $\mathrm{C}^{14}$. Incubation was done at the same temperature and light intensity.

The phytoplankton was thus divided into two fractions: smaller than $50 \mu$ (from $0.45-50 \mu$ ) and smaller than $25 \mu$ (from $0.45-25 \mu$ ).

b) One litre of the sea water was filtered through a net with $50 \mu$ pore size, and washed in one litre of the same sea water, Millipore filtered (0.8 $\mu$ pore size, and $45 \mathrm{~mm}$ diameter) (YeNTsCH \& Ryther, 1959). $125 \mathrm{ml}$ pyrex bottles, were then filled with this sea water. The remaining net-filtered sea water (i.e. the fraction smaller than $50 \mu$ ) was used to fill another series of bottles.

The samples were inoculated with radioactive sodium bicarbonate, and incubated at approximately 10,000 Lux light intensity during 4 hours.

The same treatment was given to sea water which have been passed through nets with $25 \mu$ pore size.

For each experiment of the $a$ and $b$ series, replicates were prepared, as well as a dark bottle for correction.
II - A study on the effect of the dilution of the phytoplankton population, when filtered through a net and washed in Millipore filtered sea water, was included: for each station, 50 litres of surface sea water, were filtered through a $50 \mu$ pore size net silk, and diluted in $100 \mathrm{ml}$ of Millipore $(0.45 \mu$ pore size-HA) filtered sea water. $10 \mathrm{ml}$ of this water, were diluted to $100 \mathrm{ml}, 250 \mathrm{ml}$ and $500 \mathrm{ml}$ of the same sea water.

Each sample was inoculated with the corres. ponding amount of radioactive sodium bicarbonate, necessary to give approximately the same activity for the different volumes.

III - Anderson (1965) found that 1.2 to $6,6 \%$ of the total $\mathrm{C}^{14}$ uptake in raw sea water, occurred in samples previously filtered, through filters with $0.8 \mu$ pore size. To investigate this possibility, some experiments were conducted in the following way:

The sea water was first filtered, through filter paper, Whatmann $n .^{\circ} 1$, then through glass filters, with $9 \mu$, pore size, and through a Millipore filter $0.8 \mu$ pore size. $125 \mathrm{ml}$ pyrex bottles, were filled with this sea water and inoculated with radioactive sodium carbonate. After the incubation period during 4 hours, and 10,000 Lux approximately, $100 \mathrm{ml}$ of this samples was filtered through Millipore filters of $0.45 \mu$ pore size.

Another series was prepared using different volumes of sea water, under the same conditions of illumination, and the same time for incubation. Volumes used were $50 \mathrm{ml}, 100 \mathrm{ml}, 250 \mathrm{ml}$ and $500 \mathrm{ml}$.

IV - The effect of positive and negative pressure in the different fractions.

Some studies which have been made (LASKER \& Holmes, 1957) have demonstrated that strong pressures can present a problem in the filtration of sam. ples inoculated with radioactive carbon.

Guillard \& WangersKY (1958) and TundisI (1965) suggested that the pressure applied, can be responsible for the liberation of cellular material in old cultures of flagellates. Hence, to investigate a possible effect of positive and negative pressure in the different fractions of phytoplankton, during filtration, two series of experiments were prepared:

The sea water was filtered through a silk net of $50 \mu$, inoculated with radioactive sodium bicarbonate, and incubated for 4 hours at approximately 10,000 Lux light intensity. After this time, the samples were filtered through a Millipore filter, $0.45 \mu$ pore size, under positive pressure, of $1.0,1.5,2.0 \mathrm{Kg} / \mathrm{cm}^{2}$. The same treatment was given to sea water which was passed through a silk net of $25 \mu$, and to total samples of phytoplankton (i.e. not filtered sea water).

$\mathrm{V}$ - The effect of formaldehyde in the different fractions.

Some authors (STRICKLANd \& PARsons, 1965) recommended the use of formalin, immediately at the end of the incubation period to preserve the samples. It is indicated that the formaldehyde may affect the more delicate algae. Thus, to investigate this possibility, and the effect of formaldehyde, on the different fractions, the following series of experiments was prepared: 
Twelve samples of sea water, were inoculated with radioactive sodium bicarbonate in $125 \mathrm{ml}$ pyrex and incubated for 4 hours. After this period six samples were filtered through H.A. Millipore filter $0.45 \mu$ pore size and to the remainning six of them, formaldehyde was added. Both the batches of samples, were passed through nets of $50 \mu$ and $25 \mu$ pore size. Thus, any effect caused by the use of formaldehyde to stop photosynthesis could be detected in comparison with the other samples.

An end-window Geiger Müller tube (Phillips) was used to measure the radioactivity in the filters, for all the samples. All the results are given in counts per minute.

\section{RESULTS}

\section{I - Methods of fractionation}

Table I compares the results given by the first method used (Steemann-Nielsen \& Jensen, 1957) in the three stations. This method seems to give always greater results, for the fractions smaller than $50 \mu$, unless at station II, where the average results were almost similar.

TABLE I - Results for the fractionation of total samples of phytoplankton, with the first method used (description in the text)

STATION I
Size fraction

Total

a)

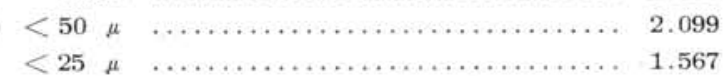

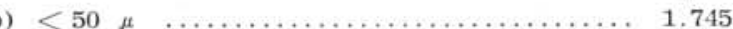

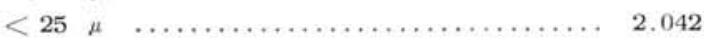

STATION II

Size fraction

epm

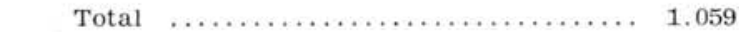

$<25 \mu \quad \ldots \ldots \ldots \ldots \ldots \ldots \ldots \ldots \ldots \ldots \ldots \ldots \ldots \ldots \ldots \ldots$

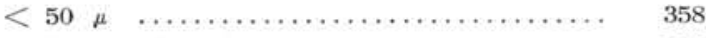

STATION III

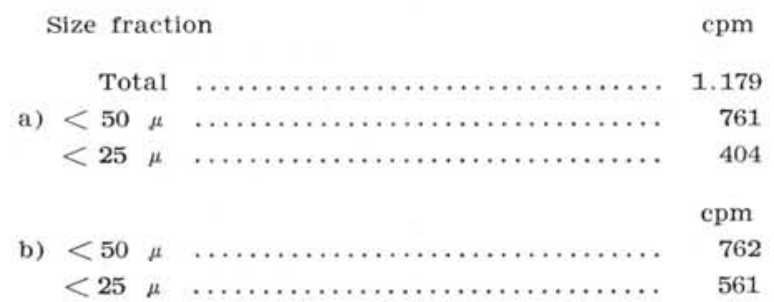

$\mathrm{a}=$ Filtered before inoculation and incubation.

$\mathrm{b}=$ Filtered after inoculation and incubation.

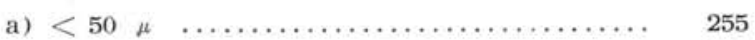

In all the three stations the average of the cpm was greater in the samples filtered through the nets after incubation. Table II, shows the results obtained with the second method (Yentsch \& RYther, 1959).

TABLE II - Results for the fractionation of total samples of phytoplankton, with the second method used (description in the text)

\section{STATION I}

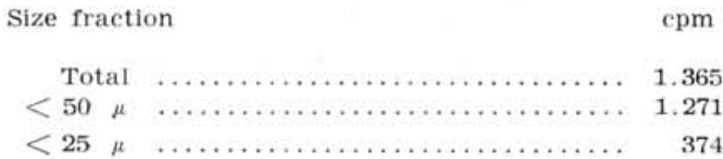

\section{STATION II}

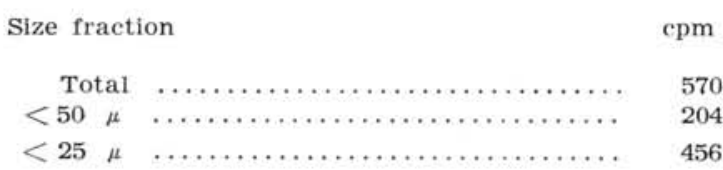

\section{STATION III}

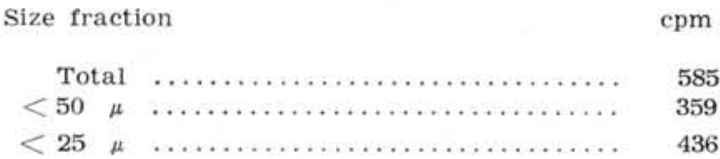

There were fluctuations in the number of cpm in all the stations studied. The fraction smaller than $50 \mu$, was the most important at station I. The fraction greater than $25 \mu$, was the most important at station II and III.

It was demonstrated that the fraction greater than $50 \mu$, was the less important regarding the $\mathrm{C}^{14}$ uptake with the two methods studied.

\section{II - Experiments with dilution of the phytoplankton populations}

In the three stations studied, concentration of the phytoplankton, and subsequent dilution in different volumes, demonstrated that differential $\mathrm{C}^{14}$ uptake occurs.

In some experiments the level of $\mathrm{C}^{14}$ uptake was depressed at volumes of 0.51 , when compared with the level of $\mathrm{C}^{14}$ uptake at volumes smaller than $0.5 \mathrm{l}$.

Table III, summarizes, the value obtained, for the three stations studied, and with increasing volumes of Millipore filtered sea water.

TABLE III - Effect of dilution of phytoplankton, in samples of different volume

DILUTION

\begin{tabular}{|c|c|c|}
\hline Volume & used & $=$ \\
\hline 50 & $\mathrm{ml}$ & $\ldots \ldots \ldots \ldots \ldots \ldots \ldots \ldots \ldots \ldots \ldots$, \\
\hline 100 & $\mathrm{ml}$ & $\ldots \ldots \ldots \ldots \ldots \ldots \ldots \ldots \ldots \ldots \ldots$ \\
\hline 100 & $\mathrm{ml}$ & $\ldots \ldots \ldots \ldots \ldots \ldots \ldots \ldots \ldots \ldots$ \\
\hline 250 & $\mathrm{ml}$ & $\ldots \ldots \ldots \ldots \ldots \ldots \ldots \ldots \ldots \ldots \ldots \ldots$ \\
\hline
\end{tabular}

\section{STATION I}

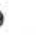


STATION II

Volume used

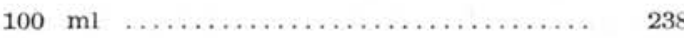

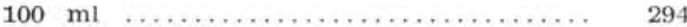

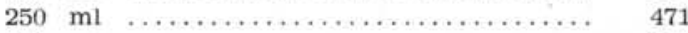

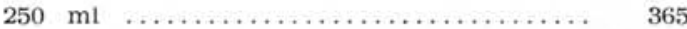

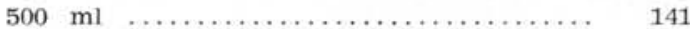

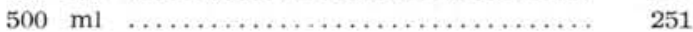

STATION III

Volume used

epm

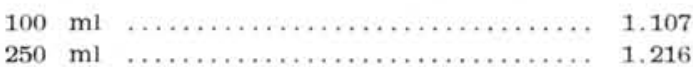

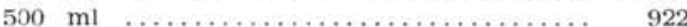

\section{III - Particulate matter}

The results for the series of experiments in which the labelled particulate matter is formed during experimental hours, are summarized in Table IV. It seems clear, that a certain amount of labelled particulate matter is present at the end of the incubation period.

TABLE IV - Particulated matter formed during experimental hours

Volume used

cpm

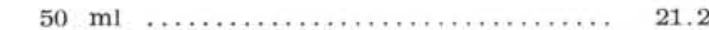

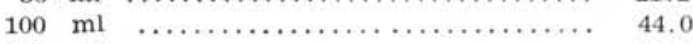

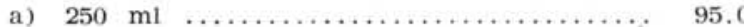

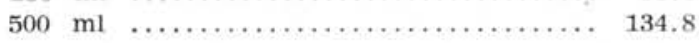

Volume used $\quad \mathrm{cpm}$

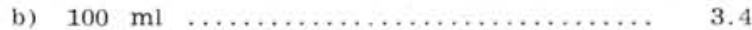

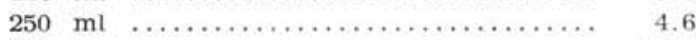

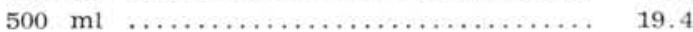

$\mathrm{a}=$ Samples submited to illumination

$\mathrm{b}=$ Dark bottle.

When the samples were filtered twice, in the same series of filters used, there was a reduction of the order of $27 \%$ in the "blank" (Table V).

The percentage of cpm in the raw sea water of different volumes used ranged from 0.3 to $1.6 \%$.

TABLE V - Particulate matter formed during experimental hours

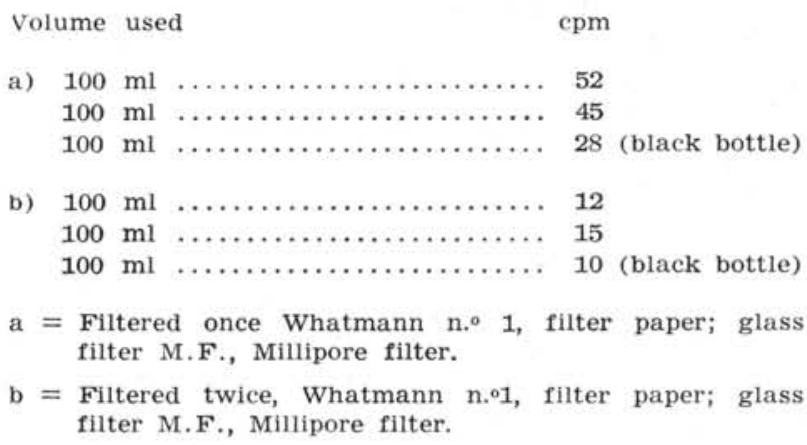

$\mathrm{b}=$ Filtered twice, Whatmann n.o1, filter paper; glass filter M.F., Millipore filter.

IV - Effect of pressure

1 - Different positive pressure applied on total samples, at the three stations studied, showed differences in the number of counts per minute. This was particularly marked at station II, where, with a pres. sure of $2.0 \mathrm{~kg} / \mathrm{cm}^{2}$ there was a considerable reduction in the number of counts. At stations I and III a less marked effect of pressure was observed (Table VI).

TABLE VI - Effect of different positive pressures on total samples

STATION I

$\mathrm{Kg} / \mathrm{cm}^{2}$

cpm (average of three replicates)
0.5
2.032
$1.0 \quad \ldots \ldots \ldots \ldots \ldots \ldots \ldots \ldots \ldots \ldots \ldots \ldots \ldots \ldots \ldots . .364$
$1.5+2.227$
$2.0 \quad \ldots \ldots \ldots \ldots \ldots \ldots \ldots \ldots \ldots \ldots . \ldots \ldots$

STATION II

$\mathrm{Kg} / \mathrm{cm}^{2}$

cpm (average of three replicates)

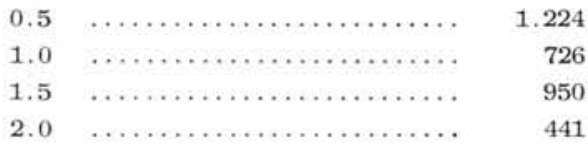

STATION III

$\mathrm{Kg} / \mathrm{cm}^{2}$

cpm (average of three replicates)

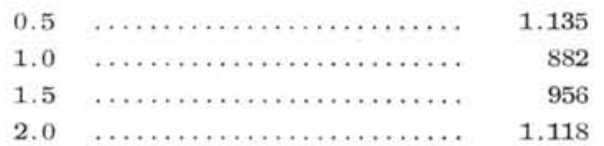

2 - A more marked effect was observed when different positive pressures, were applied in the different fractions. The fraction smaller than $25 \mu$ showed a reduction of approximately $50 \%$ in cpm at 2.0 $\mathrm{kg} / \mathrm{cm}^{2}$ in relation to the other pressures applied (Table VII).

TABLE VII - The effect of different positive pressure in the different fractions

Pressure $\quad \mathrm{cpm}{ }^{*} \quad$ Size

$\mathrm{Kg} / \mathrm{cm}^{2}$

fraction

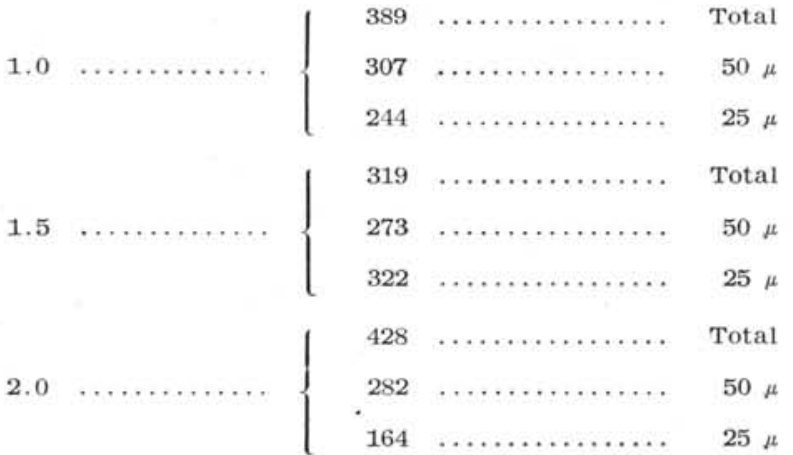

- Average of two replicates. 
The composition of the fractions was not studied, but it seems thus that the fraction smaller than $25 \mu$ was constituted by more fragile cells.

\section{$\mathrm{V}$ - The effect of formalin}

Table VIII shows the differences obtained when formalin is used to stop photosynthesis after the sam. ples were incubated during four hours.

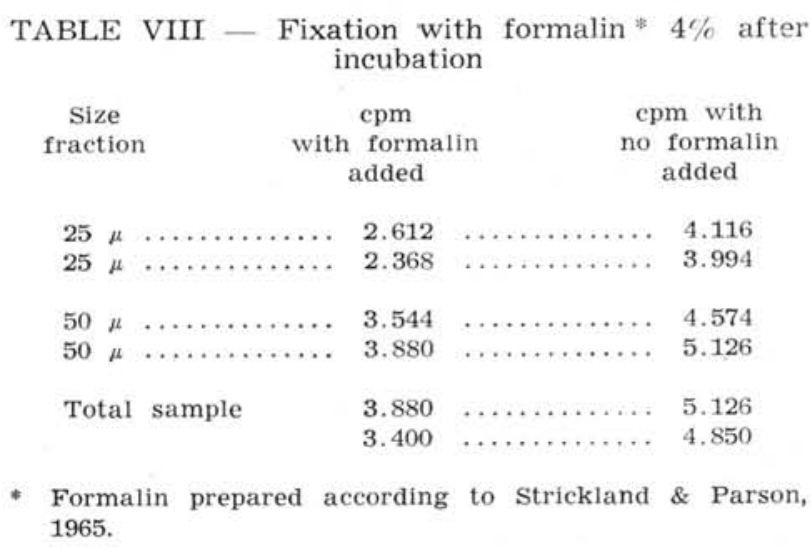

\section{DISCUSSION}

It can be postulated, that, to some extent, the first method used in the study of size distribution of phytoplankton is more reliable. The fact that the different fractions are separated before the incubation period, might be the cause of differential results. However, it is not clear such fact from the above results on the comparison of the two methods, but, filtration before the incubation period, may affect the phytoplankton causing a damage in the different fractions, lowering the $\mathrm{C}^{14}$ uptake.

SAIJO (1964), pointed out that some differences which were found in his results, and KawAmura's (1960) might be due in part to this difference in technique (i.e. filtration before and after incubation) though these differences were due also to the geographical variation of phytoplankton species.

When the filtered phytoplankton, is confined in different volumes there are differences in the $\mathrm{C}^{14}$ uptake too. These differences might arise from a "group effect" or the availability of nutrients to the different fractions. Also, it was clearly demonstrated that the greater the volume used, the greater the amount of particulate matter formed during the incubation period. It was showed that filtration through a series of filters is efficient in removing most of the particulate matter, but even so, this could not be prevented.

The causes which are responsible for the presence of higher amounts of particulate matter at the end of the incubation period are unknown. Perhaps the greater surface in the glass bottles would contribute to the formation of labelled organic aggregates. The results obtained, are lower than those quoted by $\mathrm{AN}$ DERSON (1965).
It seems, thus, from these experiments, that the use of a "blank" in certain types of experiments in estuarine waters, is indicated. This blank could be made by filtering the raw sea water, in a series of filters of different pore size, and then on Millipore or Membrane filters. The possibility of increasing the amount of labelled particulate matter during incubation is prevented but not at all excluded. This depends on the region studied. Regions with higher content of "yellow substances", might give certain amounts of labelled particulate matter after incubation. The use of formaldehyde, may be responsible for the loss of organic matter from the more delicate algae; it is clear from these experiments that the fraction smaller than $25 \mu$, is the most affected by this treatment. Further, it is generally known from earlier work, that, this fraction is composed mainly by small flagellates during the time when the study was done. It would be useful to compare this effect on the small diatoms.

Finally, in comparing the size distribution of phytoplankton in the area studied, it seems that the fraction smaller than $50 \mu$, represents the greater percentage regarding the uptake of $\mathrm{C}^{14}$. This is in agreement with earlier results (Teixeira, Tundisi \& Santoro, 1967), as well as some results obtained this year (1967, unpublished results).

These results are also in agreement with the data obtained by SAIJo (1964), Saijo \& TAKesue (1965) for the Indian Ocean. Collier \& Murphy (1962), called attention to the fact that very small diatoms and flagellates are characteristic of waters with low concentration of nutrients. Rapid multiplication of these forms would occur even under poor nutritional conditions.

Studies on the seasonal variation of the different fractions were already done (TeIXeIra et al., 1967). and data from a more detailed investigation, are being worked (Tundisi, in preparation). The causes which could influence this composition might be related to seasonal differences in the influx of nutrients. Also. the amount of humic substances added from land drainage, could be of great importance, to this seasonal variation (Prakash \& Hodgson, 1966; TeIxeira, Tundisi \& Santoro, 1968).

\section{ACKNOWLEDGEMENTS}

The authors wish to express their thanks to the "Fundação de Amparo à Pesquisa do Estado de São Paulo" for partial support of this investigation.

\section{RES UMO}

Como parte do programa de estudos do plâncton, da região lagunar de Cananéia, foi levado a efeito uma série de experimentos com o método do $\mathrm{C}^{14}$, utilizado para a determinação da fixação relativa do isótopo, em cada fração do fitoplâncton. Foram testados principalmente os métodos utilizados por STEEMANN-NIELSEN \& JENSEN (1957) e YENTSCH \& RYTHER (1959). Como complemento, foram realizados experimentos para verificação do efeito da pressão negativa sôbre as diversas frações do fitoplâncton, o 
uso de diferentes volumes para incubação das amostras, e o efeito da fixação das amostras, com formol $4 \%$ depois do período de incubação, e antes da filtração. Atenção especial foi dada ao problema de formação da matéria particulada durante o período de incubação. Com base nos resultados, são feitas sugestōes para o uso do método do $\mathrm{C}^{14}$ em águas estuarinas.

\section{B I B L I O G R A P H Y}

ANDERSON, G. C.

1964 The seasonal and geographic distribution of primary productivity off the Washington and Oregon coasts. Limnol. Oceanogr., vol. 9 , n. ${ }^{\circ}$ 2, p. 284-302.

1965. Fractionation of phytoplankton communities off the Washington and Oregon coasts. Limnol. Oceanogr., vol. 10, n. 3, p. $477-479$.

Atkins, W. G. R.

1945. Autotrophic flagellates as the major constituents of oceanic phytoplankton. Nature, Lond., vol. 156 , p. 446.

Ballantine, D.

1953. Comparison of the different methods of estimating nanoplankton. J. mar. biol. Ass. U.K., vol. 32 , n. ${ }^{\circ} 1$ p. 129-142.

Collier, A. \& Murphy, A.

1962 Very small diatoms: preliminary notes and a description of Chaetoceros galvestonensis. Science, vol. 136, n. $^{\circ} 3158$, p. 780-782.

Gessner, F 1959.

Hydrobotanik. Berlin, Deutscher Verlag Wissenschaften, vol. 2, Stotthaushalt, p. $219-221$

Guillard, R. R. L. \& Wangersky, P. J.

1958. The production of extracellular carbohydrates by some marine flagellates. Limnol. Oceanogr., vol. 3 , n. ${ }^{\circ} 3$, p. 449-454 .

Holmes, R. W.

1959. Size fractionation of photosynthesizing phytoplankton. Spec. scient. Rep. U.S. Fish Wildl. Serv., Fisheries n. ${ }^{0}$ 279, p. 69-71.

Holmes, R. W. \& Anderson, G. C.

1963. Size fractionation of $\mathrm{C}^{14}$ labelled natural phytoplankton communities. Symposium on marine microbiology. Springfield, Thomas.

KAWAMURA, T,

1960 The "Oshoro Maru" cruise 46 to the Bering sea and North Pacific in June-August, 1960, II. Data Rec. oceanogr. Obsns explor. Fishg, n. ${ }^{\circ}$ 5, p. 142-165.

LASKer, R. \& Holmes, R. W.

1957. Variability in retention of marine phytoplankton by membrane filters. Nature, ...., n. ${ }^{\circ} 180$, p. $1295-1296$.

MULLIN, M. M.

1965. Size fractionation of particulate carbon, in the surface waters of the Indian Ocean. Limnol. Oceanogr., vol. 10, n. ${ }^{\circ}$ 3 , p. $459-461$.
Prakash, A. \& HodgSON, M.

1966. Physiological ecology of marine dinoflagellates. Rep. Bedford Inst. oceanogr. Fifth a. Rep., p. 93-94.

SAIJO, Y. 1964.

Size distribution of photosynthesizing phytoplankton in the Indian Ocean. J. oceanogr. Soc. Japan, vol. 19, n. ${ }^{\circ} 4$, p 187-189.

SaIJo, Y. \& TAKesue, K.

1965. Further studies on the size distribution of photosynthesizing phytoplankton in the Indian Ocean. J. oceanogr. Soc. Japan, vol. 20 , n. $^{\circ} 6$, p. $264-271$.

SteemanN-Nielsen, E. \& Jensen, A

1957. Primary oceanic production, the autotrophic production of organic matter in the oceans. Galathea Rep., vol. 1, p. 50-125.

Strickland, J. O. H. \& Parsons, T. R.

1965 A manual of sea water analysis. Bull. Fish. Res. Bd Can., n. ${ }^{\circ} 125,205$ p.

TeIXeIra, C

1963. Relative rates of photosynthesis and standing-stock of the net-phytoplankton and nannoplankton. Bolm Inst. oceanogr. Univ. S Paulo, vol. 13, n. ${ }^{\circ} 2$, p. $53-60$.

Teixeira, C., Tundisi, J. \& Kutner, M. B.

1965. Plankton studies in a mangrove environment. II. The standing-stock and some ecological factors. Bolm Inst. oceanogr. Univ. S Paulo, vol. 14, $\mathrm{n}^{\circ} 1$, p. $13-42$

Teixeira, C., Tundisi, J. \& Santoro Ycaza, J,

1967. Plankton studies in a mangrove environment. IV. Size fractionation of the phytoplankton. Bolm Inst. oceanogr. Univ. $\mathrm{S}$ Paulo, vol. 16, n. ${ }^{\circ}$ 1, p. 39-42.

Teixeira, C., Tundisi, J. \& SANtoro YCaZA, J

1968. Plankton studies in a mangrove environment. VI. Primary production, zooplankton standing-stock and some environmental factors. Int. Revue ges. Hydrobiol. Hydrogr., vol. 53, n. ${ }^{\circ}$, (in press).

TUNDISI, J. 1965.

Some aspects of the production of extracellular substances by marine algae. Unpublished, M. Sc. thesis, Department of Oceanography, University of Southampton.

Estudos sôbre o fracionamento do fitoplâncton, e seu significado ecológico. $\mathrm{Ph}$. D. thesis, Universidade de São Paulo (in preparation).

Wood, E. J. F. \& DAvis, P. S.

1956. Importance of smaller phytoplankton elements. Nature, Lond., vol. 177, p. 438.

YentsCh, C. S. \& Ryther, J. H.

1959. Relative significance of the net-phytoplankton and nannoplankton, in the waters of Vineyard Sound. J. Cons. perm. int. Explor. Mer, vol. 4, n..$^{\circ} 2$, p. 231-236. 